\title{
Proposal of Neotype for Clostridium thermohydrosulfuricum and the Merging of Clostridium tartarivorum with Clostridium thermosaccharolyticum
}

\author{
D. MATTEUZZI, ${ }^{1}$ F. HOLLAUS, AND B. BIAVATI \\ Istituto di Microbiologia Agraria e Tecnica, University of Bologna, Bologna, Italy, ${ }^{1}$ and Sugar Research \\ Institute, Fuchsenbigl, Austria
}

\begin{abstract}
The deoxyribonucleic acid (DNA) relationships among strains of the thermophilic species Clostridium thermohydrosulfuricum, C. thermosaccharolyticum, and C. tartarivorum, other saccharolytic, proteolytic, and acetate-producing clostridia, and some sulfate-reducing bacteria were studied by DNA-DNA hybridization experiments. Strains of the species $C$. thermohydrosulfuricum were found to constitute a genotypically homogeneous group clearly unrelated to the strains of the species $C$. thermosaccharolyticum and other competitor strains used. Strains of the species C. tartarivorum showed a high level of homology with the reference strain $C$. thermosaccharolyticum ATCC 7956.The guanineplus-cytosine contents of the acetate-forming clostridia $C$. formicoaceticum and C. thermoaceticum were 34.0 and $54.0 \mathrm{~mol} \%$, respectively.
\end{abstract}

Since the first description of Clostridium thermosaccharolyticum (8), some other thermophilic saccharolytic clostridia have been described. Mercer and Vaughn (12) found tartratefermenting clostridia in different sources and defined the species $C$. tartarivorum. From extraction juices of beet sugar factories Klaushofer and Parkkinen (7) isolated a clostridium which they called $C$. thermohydrosulfuricum because of its high temperature limits for growth (up to $75^{\circ} \mathrm{C}$ ) and the striking capacity to produce large amounts of $\mathrm{H}_{2} \mathrm{~S}$ by reduction of sulfite. A comparison of strains of the three above-mentioned Clostridium species, which in addition to the study of biochemical and cultural features also included the fine structure of the cell wall surface, led to an expanded description of the species $C$. thermohydrosulfuricum $(4,13)$. The only difference that was found between $C$. thermosaccharolyticum and C. tartarivorum was the utilization of tartrate by the latter. On the contrary, C. thermohydrosulfuricum differed from the two other species not only by a higher maximum temperature growth limit of almost $10^{\circ} \mathrm{C}$, but also by having hexagonal cell wall surface patterns, in contrast to the rectangular surface patterns of $C$. thermosaccharolyticum and $C$. tartarivorum.

The present study was designed to investigate the taxonomic relationship between strains of $C$. thermohydrosulfuricum, C. tartarivorum, and C. thermosaccharolyticum by comparing the guanine-plus-cytosine $(\mathrm{G}+\mathrm{C})$ contents of their deoxyribonucleic acids (DNA) and the nucleotide sequence similarities of the DNA prepara- tions by DNA-DNA homology experiments. Reference strains of other saccharolytic, proteolytic, and acetate-forming clostridia and some sulfate-reducing bacteria were also compared with these organisms.

\section{MATERIALS AND METHODS}

Bacterial strains and culture. The bacterial strains used were as follows. Thirteen strains of $C$. thermohydrosulfuricum isolated from extraction juices of different beet sugar factories during the campaigns of 1966, 1969, 1970, and 1971 and previously identified as $C$. thermohydrosulfuricum (3) were examined; they were E100-69, E101-69, H100-69, H10169, L77-66, L91-71, L92-71, L110-69, L111-69, S100-69, S101-69, S102-70, and T15-66.

The strains of $C$. thermosaccharolyticum used were ATCC 7956 (NCIB 9385), D120-70, D90-71, ZU51, ZU53, ZU54, ZU56, ZU57, and ZU58 (from extraction juice); and ZU68, ZU69, S201-71, S202-71, S203-71, D204-71, E205-71, E207-71, and S208-71 (from white sugar). All the strains were derived from different Austrian or Italian beet sugar factories or white sugar samples.

The strains of $C$. tartarivorum used included T9-1 and T9-3R, obtained from R. H. Vaughn, University of California, Davis, Calif.

Desulfotomaculum nigrificans strains used were NCIB 8395, and NCIB 8706; and B200 and T206-71 from white sugar.

Other strains used included Desulfovibrio vulgaris NCIB 8303, C. thermoaceticum DSM 521, C. formicoaceticum ATCC 27076, C. sporogenes ATCC 319, C. bifermentans ATCC 19299, C. perfringens ATCC 13124, C. acetobutylicum ATCC 824, C. pasteurianum ATCC 6013, C. felsineum McClung 538, C. butyricum ATCC 860, C. bejierinckii ATCC 17795, and C. tyrobutyricum ATCC 25755. 
TABLE 1. G+C content and DNA homology values among the strains of clostridia studied

\begin{tabular}{|c|c|c|c|c|c|c|}
\hline \multirow{3}{*}{ Competitor strains } & \multirow{3}{*}{ Source $^{\alpha}$} & \multicolumn{4}{|c|}{ Homology $(\%)$ of reference strains } & \multirow{3}{*}{$\begin{array}{c}\mathrm{G}+\underset{\%)}{\mathrm{C}(\mathrm{mol}} \\
\%\end{array}$} \\
\hline & & \multicolumn{2}{|c|}{$\begin{array}{l}\text { C. thermo- } \\
\text { saccha- } \\
\text { rolyticum }\end{array}$} & \multirow{2}{*}{$\begin{array}{l}\text { C. thermo- } \\
\text { hydro- } \\
\text { sulfuricum } \\
\text { E100-69 }\end{array}$} & \multirow{2}{*}{$\begin{array}{c}\text { C. formico- } \\
\text { aceticum } \\
\text { ATCC } \\
27076\end{array}$} & \\
\hline & & $\begin{array}{l}\text { ATCC } \\
7956\end{array}$ & $\begin{array}{c}2 \mathrm{U} \\
51\end{array}$ & & & \\
\hline \multicolumn{7}{|l|}{$\begin{array}{l}\text { Clostridium thermo- } \\
\text { hydrosulfuricum }\end{array}$} \\
\hline E100-69 & Extraction juice & 0 & 4 & 100 & 0 & 32.0 \\
\hline E101-69 & Extraction juice & & & 80 & & 29.5 \\
\hline $\mathrm{H} 100-69$ & Extraction juice & & & 95 & & \\
\hline H101-69 & Extraction juice & 8 & 6 & 87 & & \\
\hline L77-66 & Extraction juice & & & 100 & & \\
\hline L91-71 & Extraction juice & 30 & 0 & 81 & & 32.0 \\
\hline L92-71 & Extraction juice & 35 & & 102 & & 32.0 \\
\hline L110-69 & Extraction juice & & & 95 & & 30.5 \\
\hline L111-69 & Extraction juice & & & 100 & & 31.0 \\
\hline $\mathrm{S} 100-69$ & Extraction juice & & & 102 & & \\
\hline S101-69 & Extraction juice & & & 98 & & 31.0 \\
\hline $\mathrm{S} 102-70$ & Extraction juice & & & 100 & & 31.0 \\
\hline $\mathrm{T} 15-66$ & Extraction juice & & & 87 & & 32.0 \\
\hline \multicolumn{7}{|l|}{$\begin{array}{l}\text { C. thermosac- } \\
\text { charolyticum }\end{array}$} \\
\hline 7956 & ATCC & 100 & 91 & 19 & 0 & 29.0 \\
\hline D120-70 & Extraction juice & 100 & 95 & 49 & 0 & 30.0 \\
\hline D90-71 & Extraction juice & 84 & 99 & & & \\
\hline ZU51 & Extraction juice & 88 & 100 & 10 & & \\
\hline ZU53 & Extraction juice & 85 & 92 & 40 & & 31.0 \\
\hline ZU54 & Extraction juice & 81 & 78 & 36 & & 32.0 \\
\hline ZU56 & Extraction juice & 84 & 90 & 16 & & 32.0 \\
\hline ZU57 & Extraction juice & 77 & 87 & 37 & 6 & 30.0 \\
\hline ZU58 & Extraction juice & 82 & 100 & 43 & & 31.0 \\
\hline ZU68 & White sugar & 98 & 102 & 26 & & \\
\hline ZU69 & White sugar & 97 & 88 & 15 & & \\
\hline S201-71 & White sugar & 95 & 100 & & 5 & \\
\hline $\mathrm{S} 202-7$ & White sugar & 102 & 100 & & & \\
\hline S203-71 & White sugar & 86 & 99 & & & \\
\hline D204-71 & White sugar & 91 & 102 & 16 & & \\
\hline E205-71 & White sugar & 85 & 100 & 30 & & \\
\hline E207-71 & White sugar & 86 & 98 & & & \\
\hline S208-71 & White sugar & 98 & 102 & & & \\
\hline \multicolumn{7}{|l|}{ C. tartarivorum } \\
\hline T9-3R & Vaughn & 87 & 92 & 38 & & 30.0 \\
\hline T9-1 & Vaughn & 96 & 88 & 29 & & 30.5 \\
\hline \multicolumn{7}{|l|}{$\begin{array}{c}\text { Desulfotomaculum } \\
\text { nigrificans }\end{array}$} \\
\hline 8395 & NCIB & 0 & 0 & 0 & 2 & 45.0 \\
\hline 8706 & NCIB & 10 & 17 & 0 & 0 & 45.0 \\
\hline B200-71 & White sugar & 0 & 0 & 0 & 7 & 46.5 \\
\hline $\mathrm{T} 206-71$ & White sugar & 2 & 0 & 0 & 3 & 45.5 \\
\hline $\begin{array}{l}\text { Desulfovibrio } \\
\quad \text { vulgaris } 8303\end{array}$ & NCIB & 0 & 0 & 0 & 0 & 61.0 \\
\hline C. thermoaceticum 521 & DSM & 0 & 0 & 0 & 3 & 54.0 \\
\hline C. formicoaceticum 27076 & ATCC & 16 & 4 & 7 & 100 & 34.0 \\
\hline C. sporogenes 319 & ATCC & 7 & & 0 & 10 & 26.0 \\
\hline C. bifermentans 19299 & ATCC & 21 & & 0 & 2 & 29.0 \\
\hline C. perfringens 13124 & ATCC & 0 & & 4 & 2 & 25.0 \\
\hline C. acetobutylicum 824 & ATCC & 0 & & 0 & & 29.0 \\
\hline C. pasteurianum 6013 & ATCC & 15 & & 0 & 8 & 29.0 \\
\hline C. felsineum 538 & McClung & 0 & & 0 & 2 & 25.0 \\
\hline C. butyricum 860 & ATCC & 14 & & 0 & 8 & 27.5 \\
\hline C. bejierinckii 17795 & ATCC & 10 & & 0 & 0 & 28.0 \\
\hline C. tyrobutyricum 25755 & ATCC & 14 & & 0 & 0 & 28.5 \\
\hline
\end{tabular}

${ }^{a}$ Abbreviations: ATCC, American Type Culture Collection, Rockville, Md.; NCIB, The National Collection of Industrial Bacteria, Torry Research Station, London, England; Vaughn, R. H. Vaughn, University of California, Davis, Calif.; McClung, Indiana University, Bloomington, Ind.; DSM, Deutsche Sammlun für Mikroorganismen, München, German. 
The medium employed and culture conditions for DNA isolation from saccharolytic and proteolytic clostridia were described previously (11). D. vulgaris and the strains of $D$. nigrificans were grown in Starkey Sporovibrio medium without iron salts and by replacing glucose with $0.35 \%$ sodium pyruvate. $C$. formicoaceticum and $C$. thermoaceticum were grown in the media indicated by Gottwald et al. (2). The incubation temperature was $55^{\circ} \mathrm{C}$ for thermophilic strains and $37^{\circ} \mathrm{C}$ for mesophilic species. GasPak system (BBL Microbiology Systems) was used to obtain anaerobic conditions.

DNA extraction, DNA base composition, and DNA hybridization. DNA extraction and purification procedures were performed by the method of Marmur (9); the $\mathrm{G}+\mathrm{C}$ content of the DNA preparations was determined by the thermal denaturation method (10) by using a thermal denaturation analyzer (Beckman Instruments, Inc.). DNA homology experiments were conducted with the membrane filter competition procedure under the conditions suggested by Johnson and Ordal (6). A detailed description of the procedure as used in this Institute was described previously (11). The strains used as reference organisms for DNA-DNA hybridization were as follows: $C$. thermohydrosulfuricum Klaushofer and Parkkinen E10069; C. thermosaccharolyticum McClung ATCC 7956 (NCIB 9385) and ZU51 (from extraction juice); $C$. formicoaceticum Andreesen, Gottschalk and Schlegel ATCC 27076.

\section{RESULTS AND DISCUSSION}

The $\mathrm{G}+\mathrm{C}$ content values and the results of the DNA-DNA hybridization experiments are presented in Table 1. Strains of C. tartarivorum, C. thermohydrosulfuricum, and C. thermosaccharolyticum had similar $\mathrm{G}+\mathrm{C}$ content values, ranging from 29 to $32 \mathrm{~mol} \%$. The data for the $\mathrm{G}+\mathrm{C}$ contents of $C$. formicoaceticum and $C$. thermoaceticum were the first reported in the literature for these species, whereas the values obtained for the other species examined are in close agreement with those of other authors (1, 5). Strains of the "sulfide spoilage" bacterium, $D$. nigrificans, were also included in this study. This bacterium shares several characteristics with $C$. thermohydrosulfuricum, namely, the presence of spores, thermophily, and $\mathrm{H}_{2} \mathrm{~S}$ production from sulfur compounds (3). The $\mathrm{G}+\mathrm{C}$ content values for $D$. nigrificans, ranging from 45.0 to $46.5 \mathrm{~mol} \%$, were similar to those obtained in other laboratories. These significantly different values from those of the species $C$. thermohydrosulfuricum and C. thermosaccharolyticum indicate that $D$. nigrificans cannot be closely related to the other species.

The strains of $C$. thermohydrosulfuricum formed a very homogeneous group of organisms as measured by DNA homology (Table 1). Four of the strains had from 80 to $87 \%$ homology to the reference strain (E100-69), and the remain- ing eight ranged from 95 to $102 \%$. The $C$. thermosaccharolyticum strains had similar levels of homology to the two reference strains ATCC 7956 and ZU51. The question as to whether, on account of their biochemical rèactions, it would be justifiable to consider $C$. thermohydrosulfuricum as a highly thermophilic representative of the species $C$. thermosaccharolyticum $(3,4)$ must be answered in the negative. There is no doubt that $C$. thermohydrosulfuricum, on the basis of the data obtained here, is a well-defined species. As the original type strain was lost, we propose, according to Hollaus and Sleytr (4), E100-69 as the neotype strain.

The homology results for the C. tartarivorum strains show that these organisms belong to the C. thermosaccharolyticum group. Since C. tartarivorum is the most recently assigned name, it should be considered as a synonym of $C$. thermosaccharolyticum. Therefore, as suggested by Hollaus and Sleytr (4), these strains must be regarded as representing a tartrate-fermenting biotype.

As predicted from the $\mathrm{G}+\mathrm{C}$ content values, the $D$. nigrificans strains had negligible homology with the reference strains for the other species. The $C$. formicoaceticum reference strain was unrelated to all of the organisms tested.

\section{ACKNOWLEDGMENTS}

We are indebted to J. L. Johnson, Anaerobe Laboratory, Virginia Polytechnic Institute and State University, Blacksburg, Va., for a critical review of the manuscript. This research was supported by a grant from Consiglio Nazionale delle Ricerche, Rome.

\section{REPRINT REQUESTS}

Address reprint request to: Dr. Diego Matteuzzi, Istituto di Microbiologia Agraria e Tecnica dell'Università di Bologna, Via Filippo Re 6, 40126 Bologna, Italy.

\section{LITERATURE CITED}

1. Cummings, C. S., and J. L. Johnson. 1971. Taxonomy of the clostridia: wall composition and DNA homologies in Clostridium butyricum and other butyric acid-producing clostridia. J. Gen. Microbiol. 67:33-46.

2. Gottwald, M., J. R. Andreesen, J. LeGall, and L. A. Ljungdahl. 1975. Presence of cytochrome and menaquinone in Clostridium formicoaceticum and Clostridium thermoaceticum. J. Bacteriol. 122:325-328.

3. Hollaus, F., and H. Klaushofer. 1973. Identification of hyperthermophilic obligate anaerobic bacteria from extraction juices of beet sugar factories. Int. Sugar J. 75:237-241, 271-275.

4. Hollaus, F., and U. Sleytr. 1972. On the taxonomy and fine structure of some hyperthermophilic saccharolytic bacteria. Arch. Mikrobiol. 86:129-146.

5. Johnson, J. L., and B. S. Francis. 1975. Taxonomy of the clostridia: ribosomal ribonucleic acid homology among the species. J. Gen. Microbiol. 88:229-245.

6. Johnson, J. L., and E. J. Ordal. 1968. Deoxyribonucleic acid homology in bacterial taxonomy: effect of incubation temperature on reaction specificity. J. Bacteriol. 95:893-900. 
7. Klaushofer, H., and E. Parkkinen. 1965. Zur Frage der Bedeutung aerober und anaerober thermophiler Sporenbildner als Infektionsursache in Rübenzuckerfabriken. I. Clostridium thermohydrosulfuricum eine neue Art eines saccharoseabbauenden, thermophilen, schwefelwasserstoffbildenden Clostridiums. Z. Zuckerind Boehm. 15:445-449.

8. McClung, L. S. 1935. Studies on anaerobic bacteria. IV. Taxonomy of cultures of a thermophilic species causing "swells" of canned foods. J. Bacteriol. 29:189-202.

9. Marmur, J. 1961. A procedure for the isolation of deoxyribonucleic acid from microorganisms. J. Mol. Biol. 3:208-218.
10. Marmur, J., and D. Doty. 1962. Determination of the base composition of deoxyribonucleic acid from its thermal denaturation temperature. J. Mol. Biol. 5:109-118.

11. Matteuzzi, D., L. D. Trovatelli, B. Biavati, and G. Zani. 1977. Clostridia from Grana cheese. J. Appl. Bacteriol. 43:375-382.

12. Mercer, W. A., and R. H. Vaughn. 1951.The characteristics of some thermophilic, tartrate-fermenting anaerobes. J. Bacteriol. 62:27-37.

13. Sleytr, U., and K. J. I. Thorne. 1976. Chemical characterization of the regularly arranged surface layers of Clostridium thermosaccharolyticum and Clostridium thermohydrosulfuricum. J. Bacteriol. 126:377-383. 